\title{
Sports education learning program evaluation in senior high school
}

\author{
Sulistyawati Sulistyawati *, Guntur Guntur \\ Department of Sport Science, Program Pascasarjana, Universitas Negeri Yogyakarta \\ Jalan Colombo No 1, Karangmalang, Yogyakarta, 55281, Indonesia \\ * Corresponding Author. E-mail: sulistyawati511@gmail.com
}

Received: 23 October 2019; Revised: 25 November 2019; Accepted: 9 December 2019

\begin{abstract}
The Sports Education learning program evaluation has not been completely implemented. In relation to the statement, the study aims at evaluating the Sports Education learning program in Senior High School degree. Within the conduct of the study, the evaluation involved the CIPP model. Then, the informants for the study consisted of principals, vice principals, 2 Sports Education teachers and 10 students from each of Grade X, Grade XI and Grade XII. The data were gathered by means of interview, observation and documentation. For the data analysis technique, the researcher adopted the descriptive qualitative analysis. The results of the assessment in the study show that the results of context evaluation have already contained the Core Competence and the Basic Competence from 2013 Curriculum. The Components of Input have been good and the learning process of Soccer has been well-performing. Furthermore, the Components of Output show that the mean score of Core Competence 1 and Core Competence 2 belong to the "Good" category, Core Competence 3 belongs to the "Very Good" category (82.24) and Core Competence 4 belongs to the "Good" category (80.50). Therefore, it might be concluded that the Sports Education learning program in Senior High School has been well implemented. Thus, it is recommended that the Sports Education learning program should be continued with several revisions on the process.
\end{abstract}

Keywords: CIPP Evaluation, Sports Education Learning

How to Cite: Sulistyawati, S., \& Guntur, G. (2019). Sports education learning program evaluation in senior high school. Psychology, Evaluation, and Technology in Educational Research, 2(1), 22-33. doi:http://dx.doi.org/10.33292/petier.v2i1.31

\section{INTRODUCTION}

Sports Education as an educational process that benefits the physical activities should be planned systematically in order to develop and improve individuals in terms of organic, neuromuscular, perceptual, social and emotional aspects within the framework of national education system (Afrianto, 2009; Prabowo, 2009; Yudhianto, 2010). Nurina and Sukoco (2014) in their review toward the implementation of Sports and Exercise Education in the Province of Yogyakarta Special Region mention that one of the critical problems that have been taking place is the abandonment of coaching activities in the cognitive domain (for example: the reasoning aspects and the problem-solving skills) and in the affective domain especially with regards to character education (for example: self-esteem, respect and responsibility). More specifically, according to Giriwijoyo and Sidik (2012, p. 76), the formula of Sports Education objective is that "Sports Education in the school carries three missions and one of these missions is Sports Education bears the targets for the cognitive domain, the affective domain and the psychomotor domain in wider and fundamental definition." This statement is supported by the argument of (Rosdiani, 2012), which states that "the mission of Sports Education is included in the learning objective, which covers the cognitive, affective and psychomotor domain."

However, in the implementation, the condition of Sports Education learning quality has been concerning in the elementary school degree, in the high school degree and even in the university 
degree and such condition has been proposed and reviewed by several observers of Sports Education (Kasriman, 2016, p. 365). This condition has been caused by several factors such as the limited capacity of Sports Education teachers and the limited sources that might be used for supporting the teaching process of Sports Education (Samsudin, 2008, p. 11). Not to mention, the Sports Education teachers who are responsible for the conduct of Sports Education learning direct the students more on the mastery of fundamental techniques within the sport branches (Kasriman, 2016). according to (Widoyoko, 2013), one of the important factors for achieving the educational objective is the learning process that has been implemented whereas one of the important factors for the learning effectiveness is the factors of evaluation toward both the learning process and the learning results.

Kusaeri and Suprananto (2012, p. 17) states that evaluation is viewed as an action for determining the success of the educational program that has been attended. Furthermore, (Sudijono, 2012) states that evaluation refers to the activities or the processes in assessing a subject or an object. Thereby, through evaluation teachers might identify how far the learning achievement of their students is. On the other hand, evaluation might be viewed as an assessment toward the results that have been achieved from the conduct of certain activities. Thus, evaluation might serve as a tool for measuring how far an objective has been achieved in certain period of time in accordance to the duration of the activities. Therefore, the evaluation should be accurate, valid and reliable and should also provide overall information (Gall et al., 2003, pp. 543-552). (Hasan, 2008) states that the objective of program evaluation is to assist the decision makers and yet it is the duty of evaluation to take or to make decisions.

In relation to evaluation, CIPP Model stands for Context, Input, Process and Product Approach Model, which has been developed by Stufflebeam and Shinkfield (1985). The CIPP Model basically provides very systematic manner in viewing multiple aspects on the process of curriculum development (Nuruhidin et al., 2018; Patil \& Kalekar, 2014). As a result, users who adopt the CIPP model will be enabled to evaluate schools under very comprehensive manner (Aldapit \& Suharjana, 2019; Hamalik, 2002, pp. 260-261). As having been proposed by (Mulyatiningsih, 2012, p. 121), the CIPP Model is systematically implemented in order to evaluate whether a program has been implemented in accordance to the appropriate stages. In terms of Context,the aspect that should be evaluated includes the relevance of the Sports Education learning programs in the senior high school (specifically the State 1 Senior High School Seyegan where the study is conducted) to the governing curriculum. Then, in terms of input the aspects that should be evaluated includes the educational background of the Sports Education teachers and the relevance of the Sports Education learning facilities by referring to the Regulation of the Minister of National Education Number 40 of 2008 on the standards of vocational high school facilities issued by the Board of National Education Standards (BSNP, Badan Standar Nasional Pendidikan). Next, in terms of Process the aspect that should be evaluated includes the process of Sports Education learning implementation. Last but not the least, in terms of Product the aspect that should be evaluated is the learning achievements of the students in the form of Sports Education final score for the odd semester.

Specific to the present study, from the different perspective as the caretaker of Sport-Specific Class, the State 1 Seyegan Senior High School does not only cater the needs of the talented students through exercise programs but also through Sports Education. Health and sports should go hand in hand in accordance to the curriculum that has been implemented. Such principle applies to all students, both the ones from the regular class and the ones from the sport-specific class. This matter is highly important because all students are expected to achieve the standard competences and the basic competences of Sports Education. Consequently, the learning process within the State 1 Seyegan Senior High School has been suffering from several obstacles. The tight schedule of championship games and the monitoring programs have caused some Sports Education teachers to be the mentor for the special service of sports talents while other Sports Education teachers become the coach of certain sports and focus on the training programs and championship games. One of the examples that might describe the obstacle best is that a teacher should accompany the students in a championship game and, as a result, the teacher should leave the teaching-learning process for the regular class instead of the sports-specific class. Certainly, the achievement on the objective of Sports Education becomes less maximum.

As having been explained, educational programs or learning programs should be reviewed and be evaluated regularly in order to keep in pace with the development of the science. According to 
Arikunto and Jabar (2009, p. 18), program evaluation refers to the efforts of identifying the level of implementation for a policy accurately by identfying the effectiveness of each component." Similarly, (Widoyoko, 2013) argues that program evaluation refers to the sequence of activities that aim at identifying the success of a program by identifying the components. Furthermore, according to (Arikunto \& Jabar, 2009, p. 21), the benefit of program evaluation is that program evaluation is able to gather the appropriate data in order to perform follow-up actions by providing the appropriate coaching activities. On the other hand, (Widoyoko, 2013) explains that learning program evaluation refers to the systematic and continuous process which aims at gathering, describing, interpreting and presenting information about the implementation of learning program design as the basis for the decision-making activities.

With the presence of such evaluation, teachers will be able to assess how far the learning programs in an educational unit have been implemented. Furthermore, through the evaluation results teachers will be able to perform reflection and pursue improvement in the future. Thus, teachers might consider that the monitoring activities will be useful if the supervisors provide a sense of security to the teachers by supporting the teachers' assessment althiugh their assessment might be wrong. Teachers should perceive that the supervisors are present in order to serve them and to help them to be more effective teachers (Panigrahi, 2012, p. 59). Then, departing from the overall elaboration, it is deemed necessary to observe the Sports Education learning programs that have been implemented in the State 1 Seyegan Senior High School as the operator of Sports-Specific Class. In order to assess the implementation of Sports Education learning programs, the CIPP Evaluation Model will be adopted within the conduct of the study.

\section{METHOD}

In evaluation, the research method might be categorized into quantitative method, qualitative method and mixed method (Wirawan, 2011, p. 149). Specific to the conduct of the study, the approach that had been adopted was the descriptive-qualitative method. As a result, the research procedures in the conduct of the study would result in descriptive data in the form of oral or written messages from the involved people and the behaviours from the observation. The study adopted the descriptive approach under the consideration that the CIPP (Context, Input, Process and Product) for the Sports Education learning programs in the State 1 Seyegan State Senior High School might be pursued in a more in-depth manner according to the actua conditions through the natural setting paradigm. Then, the researcher herself might be data-gatherng instrument. Then, the subjects that had been involved in the study were 1 Principal, 1 Vice Principal (Curriculum), 2 Sports Education Teachers and 10 students from Grade X, Grade XI and Grade XII. Next, the instruments that had been implemented for the measurement activities consisted of Observation, Interview and Documentation.

Table 1. Guidelines for the Instrument of Interview, Observation and Documentation

\begin{tabular}{|c|c|c|c|c|c|}
\hline No. & Evaluation & Indicators & Data Sources & Techniques & Instruments \\
\hline 1. & Context & $\begin{array}{l}\text { Relevance between the Learning } \\
\text { Instruments and the Core } \\
\text { Competences-Basic Competences of } \\
2013 \text { Curriculum }\end{array}$ & $\begin{array}{l}\text { Syllabus and } \\
\text { Lesson Plans }\end{array}$ & $\begin{array}{l}\text { Documentation } \\
\text { Interview }\end{array}$ & $\begin{array}{l}\text { Observation } \\
\text { Documentation } \\
\text { Interview } \\
\text { Guidelines }\end{array}$ \\
\hline \multirow[t]{3}{*}{2.} & Input & 1. Teacher Background & $\begin{array}{l}\text { Teacher } \\
\text { (Certificate) } \\
\text { (Letter of } \\
\text { Decision) }\end{array}$ & $\begin{array}{l}\text { Documentation } \\
\text { Interview }\end{array}$ & $\begin{array}{l}\text { Observation } \\
\text { Documentation } \\
\text { Interview } \\
\text { Guidelines }\end{array}$ \\
\hline & & 2. Teacher Training & $\begin{array}{l}\text { Teacher } \\
\text { (Certificate) }\end{array}$ & $\begin{array}{l}\text { Documentation } \\
\text { Interview }\end{array}$ & $\begin{array}{l}\text { Documentation } \\
\text { Interview } \\
\text { Guidelines }\end{array}$ \\
\hline & & 3. Sports Education Facilities & $\begin{array}{l}\text { Teacher } \\
\text { Vice Principal } \\
\text { (Equipment } \\
\text { Inventory) }\end{array}$ & Observation & $\begin{array}{l}\text { Observation } \\
\text { Sheet } \\
\text { Documentation }\end{array}$ \\
\hline 3. & Process & 1. Learning Process & $\begin{array}{l}\text { Principal } \\
\text { Vice Principal } \\
\text { Teachers }\end{array}$ & $\begin{array}{l}\text { Observation } \\
\text { Interview }\end{array}$ & $\begin{array}{l}\text { Observation } \\
\text { Sheet } \\
\text { Interview }\end{array}$ \\
\hline
\end{tabular}




\begin{tabular}{|c|c|c|c|c|c|}
\hline & & & Students & & Guidelines \\
\hline 4. & Product & $\begin{array}{l}\text { 2. Assessment Process } \\
\text { Students' Learning Results }\end{array}$ & $\begin{array}{l}\text { Principal } \\
\text { Vice Principal } \\
\text { Teachers } \\
\text { Students } \\
\text { Teacher } \\
\text { (Rapport } \\
\text { Scores) }\end{array}$ & $\begin{array}{l}\text { Observation } \\
\text { Interview } \\
\text { Documentation } \\
\text { Interview }\end{array}$ & $\begin{array}{l}\text { Observation } \\
\text { Sheet } \\
\text { Interview } \\
\text { Guidelines } \\
\text { Observation } \\
\text { Documentation } \\
\text { Interview } \\
\text { Guidelines }\end{array}$ \\
\hline
\end{tabular}

Data analysis refers to the process of organizing and ordering the data into certain fundamental pattern, category or unit in order to identify the theme and formulate working hypothesis as having been suggested by the data. Within the conduct of the study, the data analysis technique that had been adopted was the descriptive-qualitative analysis by describing and signifying the data from each aspect that had been evaluated, namely the qualitative data that had been concluded in the form of quantitative data. Then, the data from the results of input and process component evaluation were analysed and were presented by means of quantitative approach while the obstacles within the implementation of 2013 Curriculum were analysed and presented by means of qualitative approach. Eventually, the data that had been gathered were caculated and the percentage that had been attained were converted into the conversion table that had been proposed by (Sugiyono, 2015) as follows:

Table 2. Conversion on the Assessment Based on the Evaluation Percentage

\begin{tabular}{clcll}
\hline No. & \multicolumn{1}{c}{ Percentage } & Score & Category \\
\hline 1. & $81 \%-100 \%$ & A & Very Good & \\
2. & $61 \%-80 \%$ & B & Good & \\
3. & $41 \%-60 \%$ & C & Moderate & \\
4. & $21 \%-40 \%$ & D & Poor & \\
5. & $0 \%-20 \%$ & E & Very Poor & \\
\hline
\end{tabular}

\section{RESULTS AND DISCUSSIONS}

In this section, the results that have been found will be elaborated further and the elaboration will continue to the discussions toward the overall findings. Each aspect might be consulted in the following subsections.

\section{Results}

The results of the study have been attained from an interview with the Principal, Vice Principal, Sports Education Teachers and Students. The interview was performed in order to attain the in-depth results about how the context of curriculum that had been implemented in the State 1 Seyegan Senior High School was, how the learning process of Sports Education that had taken place in the State 1 Seyegan Senior High School was and how the learning results of Sports Education that had been attained in the State 1 Seyegan Senior High School were. In addition, the information that had been attained from the interview were confirmed and verified by means of verification and documentation toward the existing documents with regards to the learning programs of Sports Education in the scope of State 1 Seyegan Senior High School. The overall results that have been attained based on the context, the input, the process and the results might be described as follows (Table 3).

Table 3. Scores of Context Evaluation for the Sports Education Learning in the State 1 Seyegan Senior High School

\begin{tabular}{clrrrrc}
\hline No. & \multicolumn{1}{c}{ Informants } & E Items & Max. Score & Real Score & Percentage & Category \\
\hline 1. & Principal & 25 & 100 & 81 & $85 \%$ & Very Good \\
2. & Vice Principal & 25 & 100 & 80 & $80 \%$ & Very Good \\
3. & Teacher 1 & 25 & 100 & 84 & $84 \%$ & Very Good \\
4. & Teacher 2 & 25 & 100 & 83 & $83 \%$ & Very Good \\
& & & 82 & $82 \%$ & Very Good \\
\hline
\end{tabular}


Departing from the results of the interview and the data reduction in the efforts of generating findings, it was apparent that the learning programs in the State 1 Seyegan Senior High School had been well implemented with the mean score $82.00 \%$. The statement might be confirmed by the results of the observation and the interview that had been performed to the Principal, the Vice Principal and the 2 Sports Education Teachers. The above findings then will be elaborated into each component of context evaluation for the learning programs of Sports Education in State 1 Seyegan Senior High School.

\section{Context Evaluation for the Curriculum in the State 1 Seyegan Senior High School}

The context that had been intended in the study referred to the facts that had been found in the field in relation to the learning programs of Sports Education that had been implemented in the State 1 Seyegan Senior High School. Then, the context in the learning programs of Sports Education was as follows (Table 4).

Table 4. Scores of Context Evaluation for the Learning Programs in the State 1 Seyegan Senior High School

\begin{tabular}{clrrrrr}
\hline No. & Informants & IItem & Max. Score & Real Score & Percentage & Category \\
\hline 1. & Principal & 2 & 8 & 8 & $100 \%$ & Very Good \\
2. & Vice Principal & 2 & 8 & 8 & $100 \%$ & Very Good \\
3. & Teacher 1 & 2 & 8 & 8 & $100 \%$ & Very Good \\
4. & Teacher 2 & 2 & 8 & 8 & $100 \%$ & Very Good \\
& & & 8 & $100 \%$ & Very Good \\
\hline
\end{tabular}

Context evaluation consisted of two indicators namely the subject materials in accordance to the Minister of National Education Regulation Number 24 of 2016 on Core Competences-Basic Competences. Based on the statement by the Principal, it was apparent that the design of learning administration that had been created by the teachers referred to the Minister of National Regulation Number 24 of 2016 on Core Competences and Basic Competences for the subject materials in Curriculum 2013 within the scope of Elementary and High School Degree Education had been well implemented. The evidence was that the total score had been $100 \%$.

For analysing the relevance of Sports Education learning program materials that had been implemented in the State 1 Seyegan Senior High School, a group of syllabi and lesson plans that had been designed by the Sports Education teachers were documented. The delivery of the materials had been in accordance to the relevance in the cognitive domain and also to the Core Competences and the Basic Competences namely 10 Basic Competences in 2013 Curriculum namely 10 Basic Competences and 17 learning materials. However, in the practice the deliver of the materials had not been maximum since 16 out of 17 materials had been delivered. The material that had not been well-delivered was Swimming. The obstacle behind the situation was the inavailability of the learning facility namely swimming pool. Not to mention, the effective time allocation for the second semester had been given to the practical examination.

Prior to designing the learning administration in the form of Book 1, Book 2, Book 3, Book 4 and Book 5, the Sports Education teachers mapped the Core Competences and the Basic Competences in accordance to the Core Competences and the Basic Competences that had been formulated in the Minister of National Education Regulation Number 24 of 2006. The results of the observation that had been performed confirmed that the learning process that had been implemented was already in accordance to the 2013 Curriculum. According to the process in the 2013 Curriculum, a teacher prepares the learning programs based on the Core Competences and the Basic Competences that have been defined by the Ministry and then develops both the Core Competences and the Basic Competences into the Indicators of Competence Achievement (IPK, Indikator Pencapaian Kompetensi). Based on the above elaboration, it was clear that the design of Sports Education learning programs in the State 1 Seyegan Senior High School had been performed at the beginning of the academic year.

The method that had been implemented in designing the learning programs of Sports Education was holding an official meeting between the leaders and the subject teachers, socializing the workload and the teacher duties and also the latest regulations issued by the Ministry, analyzing the Core Competences and the Basic Competences, designing the programs, presenting the programs, validating 
Psychology, Evaluation, and Technology in Educational Research, 2 (1), 2019, 27

Sulistyawati Sulistyawati, Guntur Guntur

the programs, revising the programs (if any) and gaining the authorization for the programs by the leaders.

Input Evaluation for the Learning Programs of Sports Education in State 1 Seyegan Senior High School

The input into the learning programs of Sports Education in the State 1 Seyegan Senior High School was the educational background of the Sports Education teachers, the history of educational training and the supporting facilities for the learning programs of Sports Education in the State 1 Seyegan Senior High School.

Table 5. Scores of Input Evaluation for the Sports Education Learning in the State 1 Seyegan Senior High School

\begin{tabular}{|c|c|c|c|c|c|c|}
\hline No. & Informants & $\sum$ Item & Max. Score & Real Score & Percentage & Category \\
\hline 1. & Principal & 4 & 16 & 16 & $100.00 \%$ & Very Good \\
\hline 2. & Vice Principal & 4 & 16 & 16 & $100.00 \%$ & Very Good \\
\hline 3. & Teacher 1 & 4 & 16 & 15 & $93.75 \%$ & Very Good \\
\hline 4. & Teacher 2 & 4 & 16 & 14 & $87.50 \%$ & Very Good \\
\hline \multicolumn{4}{|c|}{ Mean score } & 15.25 & $95.31 \%$ & Very Good \\
\hline
\end{tabular}

The input evaluation was related to the educational background of Sports Education teachers and the history of educational training that the Sports Education teachers had attended in improving their competences. Based on the results of the interview, the observation and the documentation, it was apparent that the input evaluation for the learning progrms of State 1 Seyegan Senior High School belonged to the "Very Good" category wth the score 15.25 or $95.31 \%$.

Teachers' Educational Background

In relation to the learning programs, there were 2 teachers who had been teaching Sports Education in the State 1 Seyegan Senior High School. Based on the results of the observation and the documentation that had been performed, it was found that the learning programs of Sports Education had already meet the standard qualifications that had been issued by the Ministry namely the graduates of Strata 1 (S1) Sports Education Study Program. One of the teachers was actually the graduate of Sports Education, Sports and Health Study Program, Faculty of Sports Science, Yogyakarta State University, with "A" Accreditation Title. The other teacher was actually a subject teacher who had been held Certified or professional. Consequently, the results of the evaluation on the components of input already belonged to the "Very Good" Category.

Training

In order to improve the performance quality and the professionalism, the Sports Education teachers should undergo training programs. The training programs for the teachers had been one of the activities that both the government and the school held. In the same time, the independent training programs should be attended by the teachers in order to improve their sills. Within the designation of the State 1 Seyegan Senior High School as the pilot project for the implementation of 2013 Curriculum in the Senior High School Degree at the Regency of Sleman, along with the other state senior high schools, the State 1 Seyegan Senior High School had been target of the training programs as the preparation for the intended implementation. The workshop of 2013 Curriculum thus was held more frequently in the state senior high school rather than in the other senior high school. From the relevance between the instructor competencies and the training materials, it is apparent that the relevance between the instructor competencies and the materials of the training programs that had been attended belonged to the "Very Good" category with the score 15.25 or $95.31 \%$.

Facilities

Based on the results of the observation that had been conducted, it was apparent that the supporting facilities of Sports Education in the State 1 Seyegan Senior High School had already met the standards with the score 86.11 or, in other words, had already belonged to the "Very Good" category. However, some of the facilities, such as swimming pool, swimming equipment and also gymnastic equipment, had still been minimum and consequently there were several obstacles within the implementation of the learning process. 
Psychology, Evaluation, and Technology in Educational Research, 2 (1), 2019, 28

Sulistyawati Sulistyawati, Guntur Guntur

Process Evaluation for the Learning Programs of Sports Education in the State 1 Seyegan Senior High School

The evaluation process for the learning programs of Sports Education in the State 1 Seyegan Senior High School consisted of learning process, assessment and learning management. The results of the interview in this regard might be consulted in Table 6.

Table 6. Scores of Process Evaluation for the Sports Education Learning in the State 1 Seyegan Senior High School

\begin{tabular}{clrrrrc}
\hline No & Informants & $\sum$ Item & Max. Score & Real Score & Percentage & Category \\
\hline 1. & Principal & 19 & 76 & 57 & $75.00 \%$ & Good \\
2. & Vice Principal & 19 & 76 & 56 & $73.90 \%$ & Good \\
3. & Teacher 1 & 19 & 76 & 62 & $81.60 \%$ & Very Good \\
4. & Teacher 2 & 19 & 76 & 62 & $81.60 \%$ & Very Good \\
& \multicolumn{2}{c}{ Mean score } & & 59.25 & $78.00 \%$ & Good \\
\hline
\end{tabular}

Based on the results in Table 6, it was apparent that the evaluation process that had consisted of learning process, assessment and learning management earned the mean score 59.25 or $78.00 \%$ and thus belonged to the "Good" category. Each indicator in the process evaluation might be elaborated in the following sections.

In the process fo designing the lesson plans, the teachers should analyse the Core Competences and the Basic Competences of the subject first. Then, they should map and develop the Indicators of Competence Achievement, starting from the spiritual attitude to the social attitude, the knowledge aspects and finally the skills aspects. The Indicators of Competence Achievement were the indicators that the students should achieve and the teachers should implement in the learning process.

The teachers' understanding toard the use of scientific approach was written in the learning procedures that had been translated into the syllabus and the lesson plans. The relevance in this regard had been confirmed by the results of the observation that had been performed. The implementation of the remedial learning process and the enrichment learning process had been in accordance to the needs of the students during the learning process. Both the remedial learning process and the enrichment learning process had been written as well in the syllabus and the lesson plan. Then, the description on the achievement of the above scores had been supported by the results of the observation on the Sports Education teachers in the State 1 Seyegan Senior High School.

The results of the observation toward the 2 Sports Education teachers show that the mean score had been 66.50 and thus belonged to the "Good" category. At the beginning of the learning process, the teachers gave the students 10 minutes to change their clothes and then continued to the conduct of the learning process in the classroom. The teachers greeted the students and led the prayer first; then, they motivated the students and prepared the students to attend the learning process of Sports Education. Next, the teachers explained the learning objectives and also the sequence of the learning activities. In the core activities of the learning process, the teachers stimulated the students by playing a soccer game video and asking the students to analyse the soccer game by means of group discussion. Afterward, the teachers proposed challenging questions with regards to the learning materials of soccer and provided opportunities for the students to answer the questions. In turn, the teachers invited the students to ask one another and they might provide their answer based on numerous literature resources that had been read. After the activities had been done, the teachers headed to the field with the teachers as their facilitators. The students did the warm up and then performed the fundamental techniques in the soccer altogether with the game pattern that had been learned in the groups. Next, the students practiced what they had learned and the teachers gave the correction over the practice. At the end of these activities, the teachers performed the psychomotor assessment. Afterward, the students did the cooling-down and reflected on the learning process altogether. Furthermore, the teachers provided the feedback and assignment. In the closing part of the learning activities, the teachers informed the learning activities for the next meeting.

Based on the results of the interview to the students, the mean score was 82.50. This mean score was already linear to the results of the evaluation to the students and the results of the observation that had been performed. The implication was that the learning process had been well conducted. At this point, the students had been able to understand the learning materials that the teachers had delivered. The teachers delivered the learning materials easily and enjoyably: they always provided opportunities 
Psychology, Evaluation, and Technology in Educational Research, 2 (1), 2019, 29

Sulistyawati Sulistyawati, Guntur Guntur

for the students to observe, raise questions, gather the data, perform reasoning and communicate learning materials. In the same time, the students had also understood the assignment that the teachers have given.

The assessment process within the learning process refers to the stages of viewing the level of success for the learning programs that had been planned. Within the assessment process, there were several factors that became the matter of reference namely the concept understanding of the teachers and the assessment application. The factors of assessment, namely the concept understanding of the teachers and the application of authentic assessment on the learning programs of Sports Education, showed that the teachers might have understood the concept and the assessment application but the implementation in the field had not been maximum. Specifically, the teachers' understanding toward the concept and the application of portfolio-based assessment, the concept and the application of daily test and also the concept and the application of final semester examination in the State 1 Seyegan Senior High School had been good. The statement was confirmed by the process of official meeting sessions where the official educational calendar was reviewed with regards to the schedule of midsemester examination, the time mechanism for test item design and alike.

Learning management was highly important in the managing the teaching-learning process. Within the context of State 1 Seyegan Senior High School, the learning management for the Sports Education consisted of several indicators. One of the indicators was related to the relevance between the timetables and the curriculum structures (lessons and learning loads). This indicator had already belonged to the "Very Good" category. The timetables themselves had been adjusted to the teaching workloads and the curriculum structures. Specifically, the Sports Education with its practical characteristics had been given 1-6 hours of learning period every day. The categorization of the students' interest had been well implemented as well. Starting from the Academic Year 2016/2017, the categorization of the students' interest had been in accordance to the official regulations. The students' interest was categorized when the enrolment of the new students was held and had been in accordance to the criteria of the interest categorization.

Furthermore, the task division and the teaching load of the teachers had already been in accordance to the ministerial regulations namely minimum 24 hours in addition to the other duties such as homeroom teacher and officer of school health department. Then, the relevance on the number of students in each classroom within the State 1 Seyegan Senior High School had been good as well with 32 people as the number of students in each classroom. The number and the time of acceptance for the textbooks of 2013 Curriculum had been $50.00 \%$ or had belonged to the "Good" category; however, there were still many obstacles that should be dealt with. The textbooks arrived at the beginning of the academic year but these textbooks should be stamped first and should be covered as well. The whole process took a long time until all of the textbooks arrived at the students' hands.

The supports from the learning facilities within the conduct of the Sports Education learning process in the State 1 Seyegan Senior High School had been good. The facilities had already met the standards and had already been sufficient as well. However, several learning materials of Sports Education might not be practiced due to the distance between the school and the practice site and also due to the permission from the school itself, for example: Swimming.

Results Evaluation for the Learning Programs of Sports Education in the State 1 Seyegan Senior High School

The results evaluation for the learning programs of Sports Education in the State 1 Seyegan Senior High School was directed toward the students' learning results; these results were gathered from numerous examinations, assignments and even assessments that the teachers had performed in their teaching-learning process. The success of the students was determined by the minimum achievement score (KKM, Kriteria Ketuntasan Minimal). The minimum achievement score that had been assigned in the State 1 Seyegan Senior High School was B for the Core Competence 1, B for Core Competence 2 and 75 for both Core Competence 3 and Core Competence 4. In overall, the results of the Sports Education learning programs in the State 1 Seyegan Senior High School had been achieved or had belonged to the "Good" category. The results of the students from Grade X, Grade XI and Grade XII show that the Core Competence 1 at the aspects of Spiritual Attitude had belonged to the "Good" category, the Core Competence 2 at the aspects of Social Attitude had belonged to the "Good" category, the Core Competence 3 at the aspects of Knowledge had belonged to the "Very 
Psychology, Evaluation, and Technology in Educational Research, 2 (1), 2019, 30

Sulistyawati Sulistyawati, Guntur Guntur

Good" category with the mean score 82.24 and the Core Competence 4 at the aspects of Skills had belonged to the "Good" category with the mean score 80.50. These scores were the mean scores of the students in the Academic Year 2016/2017 from the learning programs of Sports Education.

\section{Discussions}

The results of the CIPP Evaluation Model for the learning programs of State 1 Seyegan Senior High School that have been elaborated in the previous sections will be discussed further in the following sections.

\section{Context Evaluation for the Curriculum of the State 1 Seyegan Senior High School}

Based on the results of the study, the context evaluation for the learning programs of Sports Education in the State 1 Seyegan Senior High School has belonged to the "Very Good" category with the score $100.00 \%$. These results have been attained from the interview with the relevant parties in relation to the programs that have been evaluated. Then, the context evaluation consists of two components namely the relevance of Sports Education and the mechanism of socialization for supporting the relevance of the Core Competences and the Basic Competences of the Sports Education. With regards to these results, (Mulyatiningsih, 2012, p. 130) state that the activities of context evaluation include tracing the results of needs analysis through the background study and reviewing the relevance between the program objectives and the students' needs.

The learning programs of Sports Education that have been taught in the State 1 Seyegan Senior High School consist of 10 Basic Competences and 17 compulsory learning materials. In the same time, these programs have also been equipped by the Competences for the Spiritual Attitude and the Social Attitude. Then, departing from the results of the study, the context evaluation reveals that the relevance of the learning materials has been in accordance to the Minister of National Education Regulation Number 24 of 2016 and thus has belonged to the "Very Good" category. The mechanism of socialization for supporting the relevance of both the Core Competences and the Basic Competences in the Sports Eduation has belonged to the "Very Good" category as well. The component of the context for the process of Sports Education learning programs socialzation is already in accordance to the already designed programs or the school's regulation with reference to the governmental regulations.

Then, the learning programs of Sports Education in the State 1 Seyegan Senior High School will always be designed at the beginning of the new academic year. The method that has been adopted in designing the learning programs of Sports Education consists of meeting session between the leadership board of the school and the teachers, socialization of workload and teacher's task as well as latest regulations issued by the Ministry, analysis on the Core Competences and the Basic Competences, program design, learning programs presentation, program validation, program revision (if any) and learning programs acknowledgement by the leadership board. These results are supported by the statement from (Patil \& Kalekar, 2014), who state that the philosophy for designing the program objectives should be in accordance to the teachers' own ideology.

Input Evaluation for the Curriculum of the State 1 Seyegan Senior High School

The input evaluation is related to the teachers' educational background, the training programs and the learning facilities of Sports Education. Based on the results of the interview, the observation and the documentation that has been performed, it is found that the input evaluation for the learning programs of Sports Education in the State 1 Seyegan Senior High School has belonged to the "Very Good" category with the score 15.25 or $95.31 \%$.

Mulyatiningsih (2012, p. 125) explains that input evaluation is performed in order to identify and assess the capability of the material resources, the tool resources, the human resources and the cost resources for executing the programs that have been selected. This fact has already been in accordancee to the standards of academic qualification for the Senior High School/Madrasah Ibtidaiyah teachers, which have been formulated in the appendix of Minister of National Education Regulation Number 16 Year 2007 on Teachers' Qualification and Competence Standards (2007, p.3). In this formulation, it is mentioned that the teachers in the Senior High School/Madrasah Ibtidaiyah Degree or in other educational degree that has been held equal should have the minimum educational academic qualification Diploma IV (D-IV)or Strata-I (S-I) for the subjects that have been taught and 
the minimum educational academid qualification should be attained from the already accredited study programs. Then, in order to improve the performance quality and the professionalism of the teachers with regards to the learning program, the Sports Education teachers should also undergo training programs. Training programs for the teachers are one of the activities that have been held by both the government and the school. In the same time, the independent training programs should be attended by the teachers as well in order to improve their skills.

Due to the designation of the State 1 Seyegan Senior High School as the pilot project for the implementation of 2013 Curriculum in the Senior High School degree along with other 7 senior high schools, the teachers in the State 1 Seyegan Senior High School automatically become the target of the training programs as part of the preparation for the implementation of the given curriculum. Consequently, there are more workshop activities that should be held by the State 1 Seyegan Senior High School in comparison to the other senior high schools.

The results of the interview with the Principal, the Vice Principal, the Head of Curriculum Department and the Sports Education Teachers show that the training that the teachers should attend has already been relevant and has also been well implemented with the score 15.25 or $95.31 \%$. These results have been confirmed by the relevance between the training materials and the teachers' needs within the learning process, the relevance between the instructors' competencies and the learning materials and the relevance between the available time allocation and the training materials. Several training programs that the Sports Education teachers have attended have already been in accordance to the their needs and to the available time allocation namely 32 meeting hours at minimum both for the direct meeting sessions and the online meeting sessions. This achievement should have met the expectation on the evaluation toward the learning programs of Sports Education. The component of input evaluation for the training programs of Sports Education teachers should be the part of the teachers' true intention in attending the training programs (Dousti et al., 2018, p. 2). Then, based on the results of the observation that has been performed, it is found that the supporting facilities for the conduct of Sports Education learning programs in the State 1 Seyegan Senior High School have already met the standards of the Minister of National Education Regulation of 2007 on the Process Standards with the score 86.11 and thus have automatically belonged to the "Very Good" category. However, several facilities have not been sufficient; consequently, the learning process suffers from certain obstacle. For example, with regards to "Swimming" learning process, the swimming pool is located quite far from the school and, not to mention, the swimming equipment has also been minimum. In the same time, the gymnastics equipment has bee minimum as well. Despite the drawback, the results of the study have been supported by the statement from (Patil \& Kalekar, 2014), who state that for a school the infrastructures such as classrooms, audio equipment, video assistance tool, special rooms, laboratories, library, garage, auditorium, playing ground and alike are highly important physical facilities.

\section{Process Evaluation for the Curriculum of the State 1 Seyegan Senior High School}

The results in the Table 5 show that the mean score process evaluation which consists of Learning Process, Learning Assessment and Learning Management has been 59.25 or $78.00 \%$ and thus has belonged to the "Good" category. The description on the results of the score achievement above is supported by the results of the observation toward the Sports Education teachers in the State 1 Seyegan Senior High School. During the observation, the learning materials that have been delivered are the big ball games or, specifically, the soccer game. The results of the observation show that the implementation of the learning process for the learning programs of Sports Education are not different from the results of the interview to the Sports Education teachers, which have been elaborated previously. The results of the observation toward the two teachers of Sports Education show that the mean score has been 66.50 and thus has belonged to the "Good" category. Furthermore, the results of the interview with the students show that the mean score has been 82.50. Thus, it might be inferred that the evaluation results from the students are linear with the interview results and the observation results. The implication is that the learning process has been well implemented. At this point, the students have understood the learning materials that the teachers have delivered. The teachers deliver the learning materials easily and enjoyably. The teachers also provide opportunities for the students to observe, raise questions, gather data, perform reasoning and communicate learning materials. In the same time, the students have also understood well the assignments that the teacher give to them. 
Output Evaluation for the Curriculum of the State 1 Seyegan Senior High School

The results in Table 5 show that the output evaluation for the assessment factor has beloged to the "Very Good" category. The statement is based on the mean score that has been equal to 23.00 or $82.10 \%$. In this regard, the students themselves are not the product but the knowledge, the skills, the attitudes and alike that the students have attained are the products (Patil \& Kalekar, 2014). These products are part of the process that has been implemented with regards to the use of the input and the process (Kardiyanto et al., 2017). Then, the results of the interview that has been proceeded to the data reduction lead to the findings that the learning programs of the State 1 Seyegan Senior High School have belonged to the "Very Good" category with the score $82.00 \%$. These findings have been confirmed by the results of the observation and the results of the interview with the Principal, the Vice Principal and the 2 Sports Education Teachers. In line with these results, (Aziz et al., 2018, p. 190) in their study have found that the educational quality of a school might be assessed in terms of facilities, methods, teaching manner by the teachers and success level among the students.

Several obstacles that have been dealt with within the implementation of Sports Education learning programs in the State 1 Seyegan Senior High School lie in the components of learning management namely the late arrival of the students' textbooks, the aspects of psychomotor-based assessment process by the Sports Education teachers and the lack of certain learning facilities for the learning programs of Sports Education. These obstacles result in the delayed achievement of core competence for several learning materials. However, departing from the overall results of the study, in general it is found that the learning process of Sports Education in the State 1 Seyegan Senior High School has not been disturbed by the presence of the Sport-Special Program. Despite the fact, there are several matters that should be evaluated and should even be improved in order to achieve the objectives of the Sports Education learning programs.

\section{CONCLUSIONS}

Based on the results of the study and also the discussions within the study with regards to the evaluation on the learning programs of Sports Education in the State 1 Seyegan Senior High School for the Academic Year 2016/2017, it might be concluded that the learning programs of Sports Education in the State 1 Seyegan Senior High School have been well implemented with the mean score $82.00 \%$. As a matter of recommendation, the learning programs of Sports Education should be continued with revisions on the "Process" variables.

\section{REFERENCES}

Afrianto, D. D. (2009). Persepsi guru non penjasorkes terhadap kinerja guru penjasorkes di SMA seKecamatan Gubug Kabupaten Grobogan. Universitas Negeri Semarang.

Aldapit, E., \& Suharjana, S. (2019). CIPP evaluation model for the coaching program of running athletes. Psychology, Evaluation, and Technology in Educational Research, 1(2). https://doi.org/10.33292/petier.v1i2.10

Arikunto, S., \& Jabar, C. S. A. (2009). Evaluasi program pendidikan (2nd ed.). Bumi Aksara.

Aziz, S., Mahmood, M., \& Rehman, Z. (2018). Implementation of CIPP model for quality evaluation at school level: A case study. Journal of Education and Educational Development, 5(1), 189206. https://doi.org/10.22555/joeed.v5i1.1553

Dousti, M., Delkhah, S., \& Darvishi, A. (2018). Evaluation of physical education faculty of University of Mazandaran. Journal of Physical Fitness, Medicine \& Treatment in Sports, 2(2). https://doi.org/10.19080/JPFMTS.2018.02.555583

Gall, M. D., Gall, J. P., Borg, W. R. D., \& Gall, J. P. (2003). Educational research: An introduction (7th ed.). Pearson Education Inc.

Giriwijoyo, S., \& Sidik, D. Z. (2012). Ilmu faal olahraga (fisiologi olahraga). Remaja Rosdakarya. Hamalik, O. (2002). Pendidikan guru berdasarkan pendekatan kompetensi. Bumi Aksara.

Hasan, S. H. (2008). Evaluasi kurikulum. Sekolah Pascasarjana Universitas Pendidikan Indonesia dengan PT Remaja .... 
Kardiyanto, D. W., Setijono, H., \& Mintarto, E. (2017). The evaluation of indonesia paralympic coaching. European Journal of Special Education Research, 2(4). https://doi.org/10.5281/zenodo.891047

Kasriman, K. (2016). Evaluasi program pembelajaran pendidikan jasmani pada sekolah dasar negeri di Kecamatan Duren Sawit, Jakarta Timur. Prosiding Kolokium Doktor Dan Seminar Hasil Penelitian Hibah, l(1) https://proceedings.uhamka.ac.id/index.php/psd/article/view/18

$365-382$.

Kusaeri, K., \& Suprananto, S. (2012). Pengukuran dan penilaian pendidikan. Graha Ilmu.

Peraturan Menteri Pendidikan dan Kebudayaan nomor 24 tahun 2016 tentang kompetensi inti dan kompetensi dasar pelajaran pada Kurikulum 2013 pada pendidikan dasar dan pendidikan menengah, Pub. L. No. 24, Peraturan Menteri Pendidikan dan Kebudayaan 5 (2016).

Mulyatiningsih, E. (2012). Metode penelitian terapan bidang pendidikan. Alfabeta.

Nurina, T., \& Sukoco, P. (2014). Upaya peningkatan karakter siswa SMA dalam permainan bola basket melalui model TPSR. Jurnal Keolahragaan, 2(1), 77-87. https://doi.org/10.21831/jk.v2i1.2605

Nuruhidin, A., Putra, F., Pamungkas, O. I., Ardiyanto, H., \& Saputro, D. P. (2018). An evaluation of powerlifting and weightlifting development program. Psychology, Evaluation, and Technology in Educational Research, 1(1), 1-8. https://doi.org/10.33292/petier.v1i1.19

Panigrahi, M. R. (2012). Implementation of instructional supervision in secondary school: Approaches, praspects and problems. Science, Technology and Arts Research Journal, 1(3), 59-67. https://www.ajol.info/index.php/star/article/view/98799

Patil, Y., \& Kalekar, S. (2014). CIPP model for school evaluation. Scholarly Research Journal for Humanity Science \& English Language, 2(10), 2615-2619.

Prabowo, Y. (2009). Persepsi guru SMA se Kecamatan Tayu Kabupaten Pati terhadap kinerja guru mata pelajaran penjas orkes tahun 2008/2009. Universitas Negeri Semarang.

Rosdiani, D. (2012). Model pembelajaran langsung dalam pendidikan jasmani dan kesehatan. Alfabeta.

Samsudin, S. (2008). Pembelajaran pendidikan jasmani dan kesehatan. Putra Grafika.

Stufflebeam, D. L., \& Shinkfield, A. J. (1985). Systematic evaluation. Kluwer-Nijhoff.

Sudijono, A. (2012). Pengantar evaluasi pendidikan. PT Raja Grafindo Persada.

Sugiyono. (2015). Metode penelitian pendidikan: Pendekatan kuantitatif, kualitatif, dan $R \& D$. Alfabeta.

Widoyoko, S. E. P. (2013). Evaluasi program pembelajaran: panduan praktis bagi pendidik dan calon pendidik. Pustaka Pelajar. https://doi.org/2013

Wirawan, W. (2011). Evaluasi teori, model, standar, aplikasi dan profesi. PT. RajaGrafindo Persada.

Yudhianto, A. (2010). Persepsi guru non penjasorkes terhadap kinerja guru penjasorkes di SMP Negeri se Kecamatan Gunungpati Kota Semarang tahun 2009/2010. Universitas Negeri Semarang. 